\title{
URODYNAMIC STUDIES IN EVALUATING DETRUSOR SPHINCTER DYSSYNERGIA AND THEIR EFFECTS ON THE TREATMENT
}

\author{
By A. Z. BuCZYŃSKI, M.D. \\ Spinal Cord Injury Department, Metropolitan Rehabilitation Centre in Konstancin, \\ Poland.
}

Summary. One of the most frequent difficulties in the rehabilitation of the hyperreflexic bladder in patients with spinal cord injuries is vesico-sphincterdyssynergia. Comprehensive urodynamic investigations of bladder pressure, abdominal pressure, urethral sphincter electromyography, cystometry and urethral flow were performed. In patients with vesico-sphincter-dyssynergia two methods of treatment were applied: conservative, by $\alpha$-blocking agents, and surgical by incision of the urethral sphincter or bladder neck. In 80 per cent conservative measures were successful in early cases, whereas this figure fell to 50 per cent when undertaken at a later stage. Ten per cent required surgical measures, usually incision of the external urethral sphincter. Sometimes in difficult cases monitoring micturition cysto-urethrography was performed.

Key words: Spinal cord injury; urodynamics; vesico-sphincter-dyssynergia.

\section{Introduction}

DisORDERS of physiological correlation between the function of the detrusor muscle and the function of the external urethral sphincter, termed vesicosphincter-dyssynergia (observed in spinal cord injured patients), may produce a considerable obstacle to the development of compensatory mechanisms of voiding. This fact is of the utmost importance in cervical and in high thoracic segments spinal cord injury, on account of the frequent incidence of spasticity. Spastic contractions of the urogenital diaphragm muscles, including the striated external urethral sphincter, may cause functional subvesical obstruction. This functional subvesical obstruction, despite the return of the reflex function of the detrusor, frequently does not permit bladder emptying. External stimulation of the bladder applied in the rehabilitation of patients with neuropathic dysfunction elicits strong reflex contraction of the detrusor but does not necessarily lead to effective voiding and frequently results in unpleasant reactions of the vegetative system, such as sweating or headache due to raised blood pressure. Administration of myorelaxant drugs such as Baclofen, Dantrium or Valium in such cases fails to yield expected results in respect of the external urethral sphincter. Application of selectively $\alpha$-blocking agents, such as Phenoxybenzamine in some cases permits satisfactory results. Conservative treatment, however, is not successful in all cases of vesico-sphincter-dyssynergia and surgical treatment becomes indispensable.

\section{The methodology of diagnostic and surgical procedure}

In the Spinal Cord Injury Department of the Metropolitan Rehabilitation 
Centre in Konstancin/Warsaw, comprehensive urodynamic investigations were performed in each case of disturbance in the formation of compensatory mechanisms of urination in spinal cord injured patients. The examination consists of simultaneous recording of four parameters significant to micturition i.e. cystometry, intra-abdominal pressure, intravesical pressure and electromyography of the external urethral sphincter. In some cases the urethral flow examination was incorporated into the examination or was performed instead of the measurement of one of the pressures. In the case of possible obstruction in the bladder neck monitoring micturition cystourethrography was also performed. The investigations are carried out using the four-channel Urolab model I I 54, produced by Life-Tech Instruments, Inc. Houston, USA (Fig. I).

Cystometry and electromyography were performed by means of special cystometry and electromyography catheters Number I2 French, with superficial electrodes (Fig. 2).

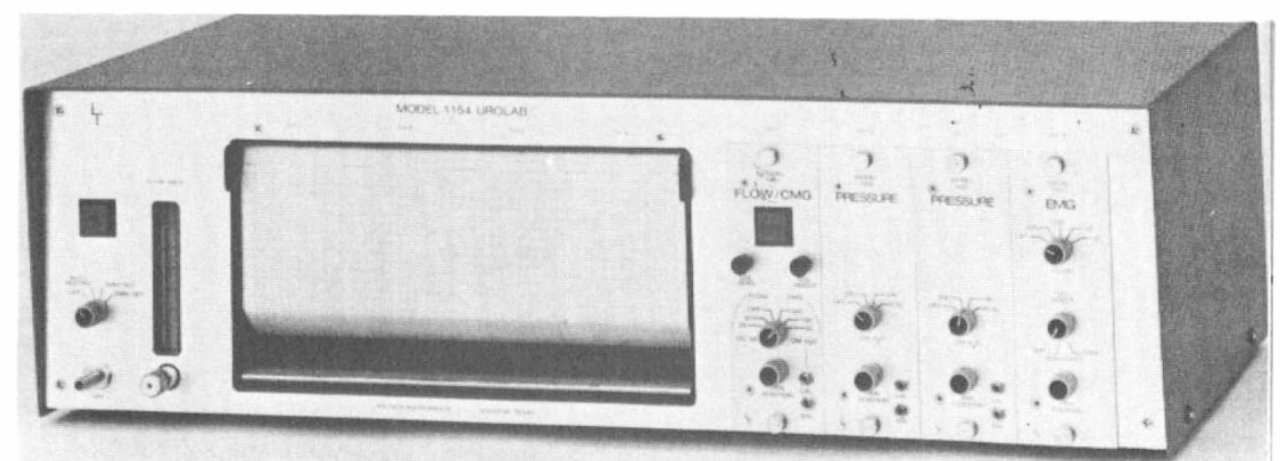

FIG. I

Four channel Model I I 54 Urolab, used for comprehensive urodynamic investigations.

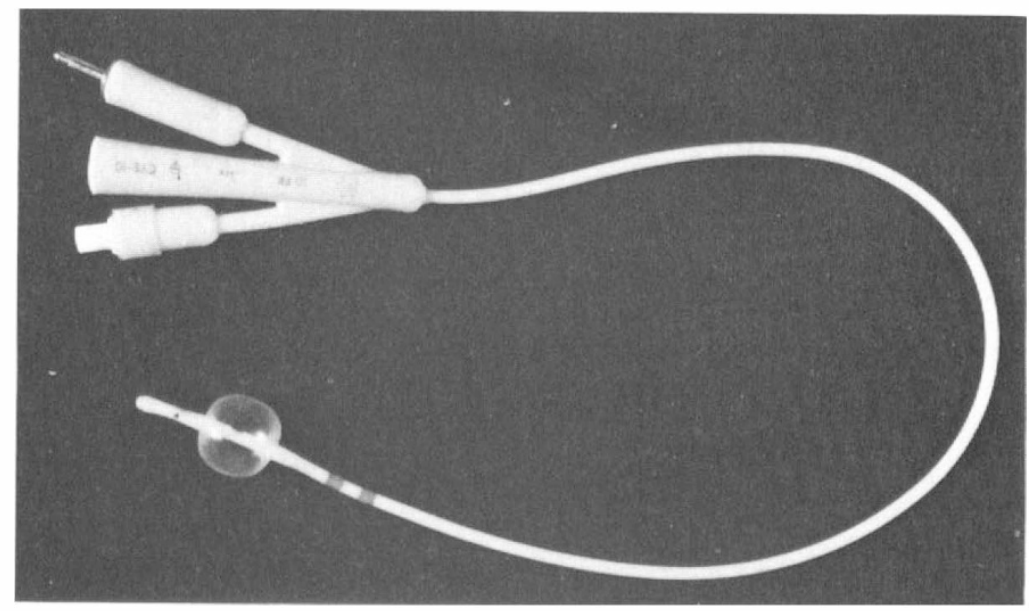

FIG. 2

Cystometry-Electromyography catheter. 

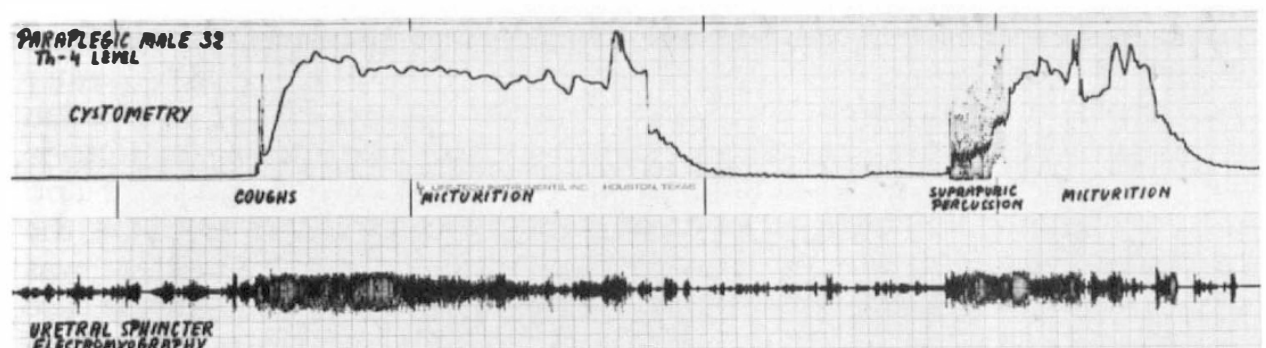
ERERRAL SPUACTER

\section{ASPOMINALL}
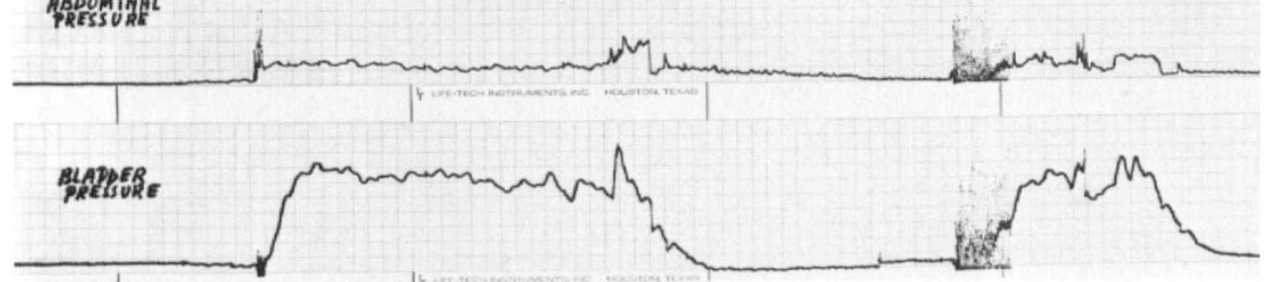

FIG. 3

Moderate degree of vesico-sphincter-dyssynergia seen during induced micturition allowing partial voiding.

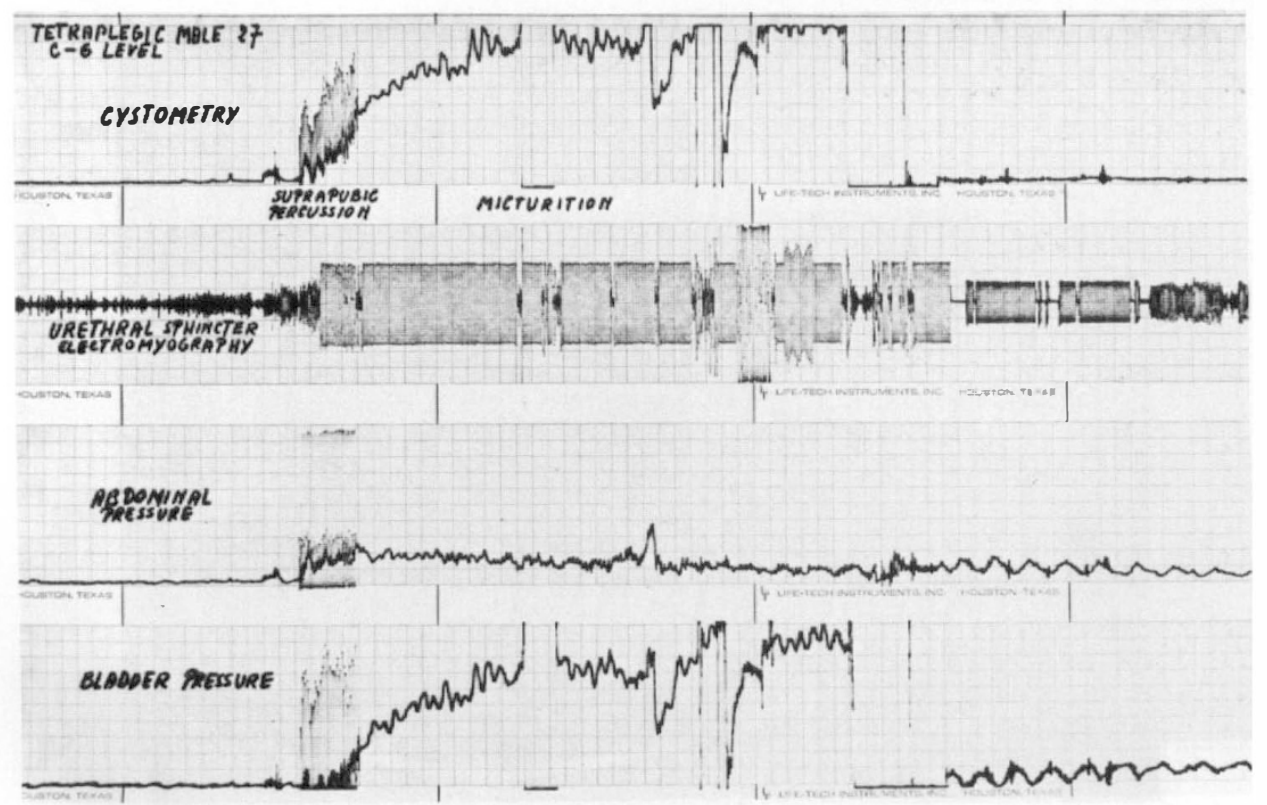

FIG. 4

High degree of vesico-sphincter-dyssynergia. No voiding. 
Intra-abdominal pressure was measured by means of water balloons placed in the rectum.

If the findings showed high values of bladder pressure, combined with enhanced activity of the external urethral sphincter during induced micturition, then the patient qualified for Phenoxybenzamine treatment according to an assigned scheme, gradually increasing the dose from 10 to $30 \mathrm{mg}$ over the period of 14 days (Figs. 3 and 4 ).

If Phenoxybenzamine treatment proved unsuccessful the patients were recommended for surgical treatment, consisting of incision of the external sphincter monolaterally at the 9 or 3 o'clock sites. In order to avoid complications the external urethral sphincter was not incised completely but only to a depth $5-8 \mathrm{~mm}$, which ensured its subutantial weakening. The incisions were made by means of a Storz urethrotome under direct vision without the use of the electric current, to avoid secondary cicatrisation. The catheter remained in the bladder for several hours after surgery until urethral bleeding ceased.

A small number of patients who showed no improvement after surgical treatment underwent monitoring cysto-urethrography, the continuation of treatment depending upon the results of this examination. If the obstruction was at the bladder neck partial electro-resection was performed at 5-7 o'clock. If the obstruction was found to be localised at the external sphincter level then incision of the sphincter was carried out on the opposite side to the former incision. Such cases were rare, however, and involved only io per cent of patients.

\section{Discussion and conclusions}

While assessing the effect of Phenoxybenzamine on the decrease of the external urethral sphincter tone it was found out that the effectiveness of this treatment depended upon the time elapsed from the injury to the beginning of treatment. In patients with vesico-sphincter-dyssynergia, treated within the first 3 months after injury, the effectiveness of conservative treatment by Phenoxybenzamine amounted to 80 per cent. In patients whose treatment was begun 3-6 months after injury to the spinal cord, the effectiveness of conservative treatment by Phenoxybenzamine amounted to slightly over 50 per cent. This may be explained by the fact that Guttmann's don't touch catheterisation method used in our Centre (Guttmann and Frankel I966), requires frequent and prolonged overcoming of the external sphincter resistance by means of the catheter, resulting perhaps in partial cicatrization of the sphincter. The functional, subvesical obstruction thus changed into an anatomical obstruction. Endoscopic observations confirmed those findings (Leriche et al., 1976). The effectiveness of surgical treatment was good and surgical failures requiring re-operation were necessary in fewer than Io per cent of patients.

Clinical observations, together with the results of urodynamic examinations, showed that the symptoms of vesico-sphincter-dyssynergia increased essentially in patients with all kinds of inflammation of the lower urinary tracts and with decubiti located near the urogenital region. These findings agree with the observations of other authors (Archimbaud, I974; Boyarsky et al., 1979; Krane et al., 1979).

In conclusion it should be noted that comprehensive urodynamic 
examinations, permitting simultaneous recording of several parameters necessary for the evaluation of micturition, have greatly facilitated the diagnosis of vesico-sphincter-dyssynergia and the assessment of the effectiveness of treatment.

\section{RÉSUMÉ}

L'une des difficultés les plus fréquentes dans la réhabilitation de la vessie hyperréflexique chez les malades qui souffrent une blessure de la moelle épinière est la dyssynergie vésico-sphinctérale. Des investigations urodynamiques compréhensives de la pression vésicale, de la pression abdominale, de l'électromyographie de sphincter uréthral, de la cystométrie et de l'écoulement uréthral ont été entreprises. Chez les malades qui souffraient de la dyssynergie vésico-sphinctérale on a employé deux méthodes de traitement: la méthode conservatrice, par des agents bloqueurs d' $\alpha$, et la méthode chirurgicale, par l'incision du sphincter uréthral ou du col de la vessie. Chez $80^{\circ}{ }_{0}$ des malades les mesures conservatrices ont réussi quand il s'agissait de cas traités avec promptitude, tandis que ce chiffre est tombé à $50^{\circ}$ o quand on a entrepris le traitement plus tard. Dix pour cent des malades avaient besoin de mesures chirurgicales, généralement une incision du sphincter uréthral externe. Quelquefois dans des cas difficiles on a entrepris la cysto-uréthrographie de surveillance de la micturition.

\section{ZUSAMMENFASSUNG}

Eine der häufigsten Schwierigkeiten in der Wiederherstellung der reflexerhöhten Harnblase bei Pazienten mit Rückenmarkverletzung ist die Blasensphinkter-Sinergiestörung. Man hat umfassende urodynamische Forschungen des Blasendrucks, des Magendrucks, der Balsensphinkter-Elektromyographie, der Zystometrie und des urethralen Durchflusses unternommen. Bei Pazienten mit Blasensphinkter-Sinergiestörung hat man zwei Behandlungsmethoden angewendet: die erhaltungsmässige Methode, durch $\alpha$-blokierende Mittel, und die chirurgische, durch Einschnitt des urethralen Sphinkters oder des Blasenhalses. Bei $80^{\circ}{ }_{0}$ der Pazienten sind die erhaltungsmässigen Massnahmen erfolgreich bei früher Behandlung gewesen, diese Ziffer ist doch bis $50^{\circ}$ o gefallen, wenn man die Behandlung erst an einem späteren Zeitpunkt unternommen hat. Zehn Prozent der Pazienten brauchten chirurgische Massnahmen, normalerweise Einschnitt des Harnröhrenaussensphinkters. Manchmal hat man in schwierigen Fällen miktionüberwachende Zystourethrographie unternommen.

\section{REFERENCES}

ARchimbaud, J. P. (1974). Les Dysfonctionnements vesico-sphinctériens neurologiques. 68 Session Association Francaise D'urologie Masson and C, Paris. II $3-135$.

Boyarsky, S., Labay, P., Hanick, P., Abramson, A. S. \& Boyarsky, R. (I979). Care of the patient with neurogenic bladder. Little, Brown and Company, Boston. 27-29.

GutTMANN, L. \& FrankeL, H. (1966-67). The value of intermittent chatheterization in the early management of traumatic paraplegia and tetraplegia. Paraplegia, 4, 63-83.

Krane, R. J., Siroky, M. B. (1979). Clinical Neuro-Urology. Little, Brown and Company, Boston. I 5 I-I 53 .

Leriche, A., Archimbaud, J. P., Berard, E., Minaire, P. \& Bourret, J. (1976). Differential diagnosis and limitations of external sphincterotomy. Paraplegia, I3, $280-285$.

THE REMAINDER OF THE PAPERS TO BE PUBLISHED FROM THIS MEETING WILL APPEAR IN THE IMMEDIATE SUBSEQUENT ISSUES OF PARAPLEGIA, INCLUDING THE DISCUSSIONS ON THE SESSION ON URODYNAMICS 